at first directed this work, but later on was content to leave it almost ontirely in the capable hands of his assistant. The work grew in volume and altered in character with the change from the Finsbury to the South Kensington College, with the establishment of three-year College day-courses, and with the rapid development of electrical engineering. As years passed, the laboratories had to be enlarged and their equipment increased, and many new members of the staff had to be engaged. Mather throughout remained in control. The main work of Mather's life consisted in the development of these laboratories and in the constant assistance given by him to those who worked in them whether as ordinary course students or as exceptional ones, like Duddell, carrying out important original work.

For many years, Mather could not lecture since his speaking suffered from an impediment so serious that he often had to resort to paper to explain what he wished to say. He was quite unable to take part in the discussions at the Institution of Electrical Engineers, or at the Physical Society. Had he been able to do so, he would have been more adequately appreciated outside the College than was the case. His struggles to overcome his disability were at times pathetic, but during and after 1914, to the astonish. ment and delight of everyone who knew him, he was able to give lectures. These were highly esteemed by his students.

From the pure science point of view, Mather's most valuable work was an investigation concerning details in the improvement of the standard cell and involving an accurate determination of its electromotive force. This work formed the subject of papers to the Royal Society, and was probably the main factor determining his election to the fellowship of the Society.

Technical men will remember Mather best for a number of papers written, mostly in conjunction with Prof. Ayrton, dealing with improvements in the construction of electrical instruments of all kinds. An instance is a set of papers on galvanometers and accessories such as the well-known Ayrton-Mather shunt. Another consists of his work on electrostatic voltmeters, which involved most skilful and careful design. These instruments were widely used in practice, since at the time they were first produced they were much wanted and were the best available instruments of their kind. The precision wattmeter of Mather and Duddell is another instance of the excellence and care in detail of Mather's work. First-rate instruments and appliances suitable for college or industrial testing are now commonplace articles of commerce, but such a result could only be reached after much previous work had been done in laboratories established for technical teaching. Mather was one of the earliest and ablest pioneers in this work.

In nature, Prof. Mather was most modest and retiring. He was always kindly and willing to help in either simple or advanced work, and never wished to have such help acknowledged in public. He was personally much liked and was held in honour by all who knew him. It would be hard to value too highly the influence of a man who spent so many years guiding the laboratory training of ordinary students and in helping in the research work of others, many of whom have become highly distinguished men.

\section{Prof. Albert Griffiths}

Prof. Albert Griffiths was born at Chester on October 8,1867 , and after the removal of his family to Manchester was educated at the Manchester Central School, the Royal College of Science, London, and in 1887 won the Dalton entrance scholarship to the Owens College, Manchester, then one of the constituent colleges of the Victoria University. He was one of the first students to read for the honours degree in physics of the University, and at the end of his first year was awarded the Heginbottom Scholarship. He obtained the degree of B.Sc. with first-class honours in 1890, and went to Germany to continue his studies at Freiburg.

In 1893 Griffiths was elected to a Bishop Berlkley fellowship at the Owens College, and commenced a series of electrical researches, an account of which he published in the Philosophical Magazine, vol. 39, in 1895. He was appointed demonstrator in physics on the termination of his fellowship in 1895 and lecturer in physics at University College, Sheffield, in 1898.

Griffiths obtained his D.Sc. degree in 1899 and in the following year, after acting as head of one of the students' hostels at Sheffield, was appointed head of the physics department of Birkbeck College, London, and ultimately professor of physics. $\mathrm{He}$ held this position until his retirement in 1933, and founded a school of research which concerned itself mainly with problems of diffusion of salts in solutions and improvements in the methods of determining coefficients of diffusion. Heart trouble set in during the summer of 1935 and became rapidly worse early in 1937 ; he died on May 24. He leaves a widow and one son.

WE regret to announce the following deaths :

Prof. H. E. Armstrong, F.R.S., emeritus professor of chemistry in the Imperial College of Science and Technology, City and Guilds (Engineering) College, on July 13, aged eighty-nine years.

Dr. A. A. Bialinycki-Birula, formerly director of the Zoological Museum of the Russian Academy of Sciences, known for his zoological work in the Arctic and for systematic work on scorpions and Solifugidæ, aged seventy-three years.

The Right Hon. Lord Ernle, M.V.O., president of the Board of Agriculture and Fisheries in 1916-19, who received the Gold Medal for 1935 of the Royal Agricultural Society "for distinguished service to the farming industry", on July 1, aged eighty-five years.

Prof. A. W. Gibb, emeritus professor of geology in the University of Aberdeen, on July 12, aged seventy-three years. 